\title{
Jumlah Leukosit, Neutrofil, Limfosit, dan Monosit sebagai Prediktor Infeksi dengue pada Anak dengan Gizi Baik di Fasilitas Kesehatan dengan Sumber Daya Terbatas
}

\author{
Adek Herlina Tanjung, Nurnaningsih, Ida Safitri Laksono \\ Departemen Ilmu Kesehatan Anak Fakultas Kedokteran Universitas Gadjah Mada/RSUP Dr. Sardjito, Yogyakarta
}

\begin{abstract}
Latar belakang. Infeksi virus dengue merupakan mosquito borne disease yang sering dijumpai di dunia. Demam pada awal sakit karena infeksi dengue dan bukan dengue sangat sulit dibedakan. Di fasilitas kesehatan dengan sumber daya terbatas diperlukan pemeriksaan darah sederhana untuk membantu mendiagnosis dengue. Jumlah leukosit, neutrofil, limfosit, dan monosit pada awal penyakit dapat membantu memprediksi diagnosis dengue.

Tujuan. Mengetahui apakah jumlah leukosit, neutrofil, monosit, dan limfosit pada anak dengan gizi baik dapat digunakan sebagai prediktor untuk infeksi dengue di fasilitas kesehatan terbatas.

Metode. Nested case control yang terdapat dalam rancangan kohort. Digunakan data rekam medis Januari 2009 sampai Januari 2011. Dilihat perbedaan pada hari ke-3 dan 4 jumlah leukosit, neutrofil, limfosit, dan monosit antara kelompok infeksi dengue dan non dengue menggunakan chi square dan regresi logistik.

Hasil. Terdapat 124 anak dengan gizi baik, terdiri atas masing-masing 62 anak kelompok dengue dan non dengue. Leukopeni merupakan prediktor untuk mendiagnosis dengue pada hari ke-3 demam dengan adjusted odds ratio 10,32 (IK 95\% 4,31-24,53; $\mathrm{p}=0,001)$. Pada hari ke-4 demam, leukopeni dan limfositosis adalah prediktor untuk mendiagnosis dengue dengan adjusted odds ratio 13,84 (IK95\% 4,92-38,88; $\mathrm{p}=0,001)$ dan 4,66 (IK95\% 1,73-12,59; $\mathrm{p}=0,002)$.

Kesimpulan. Leukopeni dan limfositosis pada anak dengan gizi baik merupakan prediktor untuk mendiagnosis infeksi dengue pada awal demam. Sari Pediatri 2015;17(3):175-9.
\end{abstract}

Kata kunci: infeksi dengue, faktor prediktor, hitung jenis leukosit

\section{Leucocyte, Neutrophil, Lymphocyte and Monocyte Profiles as Early Predictors for Dengue in Children with Good Nutritional Status in Limited Resources Setting}

\author{
Adek Herlina Tanjung, Nurnaningsih, Ida Safitri Laksono
}

\begin{abstract}
Background. Dengue infection is the most important mosquito borne disease around the world. In the early phase, the clinical manifestation might be difficult to be differentiated between dengue and non dengue infection. Therefore, simple blood examination is needed, particularly in health facilities with limited resources. The profile of leucocyte, neutrophil, lymphocyte and monocyte is one of the most common examination to be performed.

Objective. To observe leucocyte, neutrophil, lymphocyte and monocyte profile during the $3^{\text {rd }}$ and $4^{\text {th }}$ day of fever in children with good nutritional status and its role to predict dengue infection.

Method. A nested case control study was conducted using medical records. The profile of leucocyte, neutrophil, lymphocyte and monocyte during the $3^{\text {rd }}$ and $4^{\text {th }}$ day of fever were analiyzed using chi-square and logistic regression

Results. From January 2009 through January 2011, 124 medical records of children with good nutritional status were recovered, of whom 50\% (62) had dengue infection and 50\% (62) had non dengue infection based on clinical manifestation and serology results. At the $3^{\text {rd }}$ day of fever, children with dengue infection had significant leucopenia compared to those who had non dengue infection with adjusted odds ratio of 10.32 (CI 95\% 4.31-24.53, $\mathrm{p}=0.001)$. At the $4^{\text {th }}$ day of fever, leucopenia and lymphocytosis are the predominant factors for diagnosing dengue infection with adjusted odds ratio of 13.84 (CI 95\% 4.92-38.88, $\mathrm{p}=0.001$ ) and 4,66 (CI 95\% 1.73-12.59, $\mathrm{p}=0.002)$ respectively.

Conclusion. Leucopenia and lymphocytosis are predicting factors for diagnosing dengue infection in children with good nutritional status in the early phase of disease. Sari Pediatri 2015;17(3):175-9.
\end{abstract}

Keywords: dengue infection, predicting factors, profile of leucocyte count and its differential

Alamat korespondensi: Dr. Adek Herlina Tanjung, Departemen Ilmu Kesehatan Anak, Fakultas Kedokteran Universitas Gadjah Mada/RSUP Dr. Sardjito Yogyakarta, Jalan Kesehatan No. 1 Sekip Yogyakarta 55284, Indonesia. Tel. +62-274-561616, E-mail: ạdek_herlina_tanjung@yahoo.co.id 
$\mathrm{I}$ nfeksi virus dengue adalah mosquito borne disease yang terpenting di dunia. Di negara tropis, penyakit ini menyebar secara endemik dan menginfeksi lebih kurang 100 juta manusia setiap tahunnya, setengah jutanya adalah kasus DBD (demam berdarah dengue). Sekitar 22.000 kematian terjadi pada anak-anak, 90\% kasus DBD tersebut adalah anak di bawah 15 tahun $^{1,9}$.

Gejala demam pada awal sakit karena infeksi dengue dengan bukan dengue sangat sulit dibedakan. ${ }^{15}$ Sampai saat ini belum tersedia alat diagnostik sederhana dan terjangkau untuk membedakan infeksi dengue dengan penyakit epidemik dengan gejala demam secara dini. ${ }^{12}$

Pemeriksaan laboratorium untuk mendiagnosis infeksi dengue sangat beragam dan tidak semua dapat dilakukan di laboratorium diagnostik. Hingga saat ini, pemeriksaan hematologi sederhana, seperti hitung jumlah leukosit, neutrofil, monosit, dan limfosit banyak digunakan untuk membantu penegakan diagnosis dengue karena dapat dilakukan di berbagai laboratorium, bahkan Puskesmas. ${ }^{14}$

Abnormalitas hematologi yang sering muncul pada infeksi dengue adalah leukopenia, trombositopenia, dan gangguan koagulasi. Pada awal demam, jumlah leukosit dapat normal atau dengan predominan neutrofil kemudian menurun pada hari ketiga sampai kedelapan. Pada umumnya, terjadinya leukopeni bersamaan dengan trombositopeni, yaitu mulai hari ketiga demam. Pada syok berat dapat dijumpai leukositosis dengan neutropenia absolut. Hal lain yang menarik adalah ditemukan cukup banyak (20\%-50\%) limfosit bertransformasi atau atipik dalam sediaan apus darah tepi yang dikenal sebagai limfosit plasma biru. ${ }^{4,5}$

Beberapa penelitian mengatakan bahwa pemeriksaan sumsum tulang penderita dengue pada awal demam terdapat hipoplasia sumsum tulang dengan hambatan dari semua sistem hemopoesis yang memberi kontribusi untuk terjadinya leukopenia, termasuk hitung jenisnya yaitu neutropenia, limfositosis relatif, dan monositopenia. Mekanisme penekanan sumsum tulang pada infeksi dengue terjadi akibat dari proses penekanan virus secara langsung ataupun karena produksi sitokin proinflamasi. ${ }^{5,9}$

Pada saat ini, penegakan diagnosis infeksi dengue di rumah sakit kabupaten atau Puskesmas di daerah perifer menggunakan gejala klinis dan pemeriksaan penunjang sederhana. Pemeriksaan leukosit dan apusan darah tepi adalah salah satu pemeriksaan laboratorium sederhana dan tersedia di sebagian besar rumah sakit dan Puskesmas di daerah perifer di Indonesia. Penelitian ini bertujuan untuk meneliti lebih lanjut tentang hitung jumlah leukosit, neutrofil, monosit, dan limfosit untuk membantu memprediksi diagnosis infeksi dengue secara cepat dan tepat. Diharapkan, penelitian ini dapat memberikan kontribusi sebagai salah satu parameter diagnosis dini pada infeksi dengue.

\section{Metode}

Penelitian observasional dengan rancangan nested case control. Populasi terjangkau pada nested case contolberasal dari populasi studi kohort, yaitu pasien anak demam hari ke-3 dan ke-4 yang dirawat di Instalasi Kesehatan Anak (INSKA) RSUP Dr. Sardjito Yogyakarta mulai Januari 2009 sampai Januari 2011. Kelompok kasus diidentifikasi dari studi kohort yang mengalami efek, yaitu terdiagnosis infeksi dengue dan memenuhi kriteria inklusi dan eksklusi. Kelompok kontrol adalah yang tidak mengalami efek yaitu terdiagnosis infeksi bukan dengue. Pada kedua kelompok dipilih yang berstatus gizi baik. Faktor prediktor adalah faktor yang dapat memprediksi diagnosis infeksi dengue, yaitu jumlah leukosit, neutrofil, monosit, dan limfosit. Kelompok kasus kemudian dibandingkan dengan kelompok kontrol melalui analisis statistik.

Tabel 1. Karakteristik dasar

\begin{tabular}{lccc}
\hline Variabel & Kasus & Kontrol & $\mathrm{p}$ \\
& $\mathrm{N}=62$ & $\mathrm{~N}=62$ & 0,85 \\
\hline Jenis kelamin, n (\%) & & & \\
$\quad$ Laki-laki & $25(40,3)$ & $24(38,7)$ & \\
$\quad$ Perempuan & $37(59,7)$ & $38(61,3)$ & \\
Umur (tahun)* & $6,35 \pm 3,0$ & $8,1 \pm 3,5$ & 0,001 \\
Lama demam sebelum masuk rumah sakit (hari)* $_{\text {Lama perawatan (hari)* }}$ ( $^{*}$ & $3,65 \pm 0,48$ & $4,03 \pm 0,57$ & 0,001 \\
\hline
\end{tabular}

*rerata $\pm(\mathrm{SB})$ 
Analisis univariat dengan $\mathrm{x}^{2}$ (chi square) dilakukan untuk menganalisis hubungan masing-masing faktor prediktor terhadap kejadian infeksi dengue. Ukuran kekuatan hubungan dinyatakan dengan odds ratio (OR) dengan interval kepercayaan 95\%. Nilai $\mathrm{p}<0,05$ dianggap bermakna secara statistik. Selanjutnya, untuk variabel bebas yang pada analisis univariat mempunyai nilai $\mathrm{p}<0,25$ akan dilakukan analisis multivariat dengan analisis regresi logistik.

\section{Hasil}

Jumlah subyek yang memenuhi kriteria inklusi dan eksklusi sebesar 124 anak, terdiri atas 62 kelompok kasus dan 62 kontrol. Karakteristik data subyek penelitian tertera pada Tabel 1. diagnostik Sutaryo ${ }^{13}$ dan Nany ${ }^{10}$ yang menyebutkan sensitivitas tertinggi terdapat pada titik potong leukosit $<5000 \mathrm{sel} / \mathrm{mm}^{3}$, dengan masing-masing sensitivitas $65,69 \%$ dan $94,44 \%$, Kalayanarooj dkk ${ }^{6}$ mencatat sensitivitas leukopeni pasien dengue $91,19 \%$, dengan spesifisitas, positive predictive value (PPV), dan negative predictive value (NPV) masing-masing 59,83\%, $68,56 \%$, dan $87,61 \%$. Kami mendapatkan jumlah leukosit lebih rendah pada hari ke-3 dan ke- 4 demam pada pasien dengue dibandingkan bukan dengue, dengan nilai aOR yang cukup tinggi yaitu 10,32 (IK95\% 4,31-24,53) pada hari ke-3 dan aOR 13,84 (IK95\% 4,92-38,88) pada hari ke-4 sehingga dapat disimpulkan kejadian leukopeni pada infeksi dengue 10,32 dan 13,84 kali lebih besar dibandingkan bukan dengue pada hari ke-3 dan ke-4. Peningkatan risiko leukopeni pada hari ke-4 dibandingkan dengan ke-3 dikarenakan perjalanan penyakit tersebut. Dikatakan

Tabel 2. Leukopeni, neutropeni, limfositosis, dan monositopeni sebagai faktor prediktor infeksi*

\begin{tabular}{lcccccc}
\hline \multirow{2}{*}{ Variabel } & \multicolumn{3}{c}{ Bivariat } & \multicolumn{3}{c}{ Multivariat } \\
\cline { 2 - 6 } & OR & IK95\% & $\mathrm{p}$ & aOR & IK95\% & $\mathrm{p}$ \\
\hline Leukopeni & 11,79 & $5,07-27,3$ & 0,001 & 10,32 & $4,31-24,53$ & 0,001 \\
Neutropeni & 2,87 & $1,38-5,95$ & 0,004 & 1,91 & $0,72-5,62$ & 0,189 \\
Limfositosis & 3,80 & $1,56-9,17$ & 0,002 & 1,82 & $0,50-5,63$ & 0,297 \\
Monositopeni & 1,25 & $0,46-3,44$ & 0,663 & & & \\
\hline
\end{tabular}

*(sampel darah diambil hari ke-3)

Tabel 3. Leukopeni, neutropeni, limfositosis dan monositopeni sebagai faktor prediktor infeksi*

\begin{tabular}{lcccccc}
\hline Variabel & \multicolumn{3}{c}{ Bivariat } & \multicolumn{3}{c}{ Multivariat } \\
\cline { 2 - 6 } & OR & IK95\% & P & aOR & IK95\% & P \\
\hline Leukopeni & 19,60 & $7,24-53,07$ & 0,001 & 13,84 & $4,92-38,88$ & 0,001 \\
Neutropeni & 6,23 & $2,83-13,74$ & 0,001 & 1,98 & $0,67-5,87$ & 0,22 \\
Limfositosis & 8,15 & $3,42-19,43$ & 0,001 & 4,66 & $1,73-12,59$ & 0,002 \\
Monositopeni & 2,97 & $1,13-7,79$ & 0,02 & 1,67 & $0,42-6,59$ & 0,46 \\
\hline *
\end{tabular}

*(sampel darah diambil hari ke-4)

\section{Pembahasan}

Pada infeksi dengue, leukopeni telah diketahui sejak lama. Beberapa penelitian menyebutkan bahwa leukopeni selalu ada, umumnya penurunan terjadi antara 3000-5000 sel $/ \mathrm{mm}^{3}$, walau jumlahnya mungkin dapat menurun sampai $1200 \mathrm{sel} / \mathrm{mm}^{3} .{ }^{13}$ Batasan leukopeni menurut WHO 2011 adalah jika jumlah leukosit $\leq 5000 \mathrm{sel} / \mathrm{mm}^{3}$. Serupa dengan penelitian uji leukopeni pada infeksi dengue disebabkan depresi sumsum tulang akibat proses penekanan oleh virus secara langsung ataupun mekanisme melalui produksi sitokin proinflamasi. Sumsum tulang pada hari ke-4 mengalami hiposelular dengan tidak adanya granulopoesis, hambatan dari semua sistem hemopoesis ini juga menyebabkan neutropeni dan monositopeni, ${ }^{5,9,13}$ neutrofil mulai turun pada hari ke-3 sampai hari ke- 8 demam. ${ }^{16}$ 
Kami mendapatkan jumlah neutrofil dan monosit pasien dengue lebih rendah dibandingkan dengan bukan dengue, walaupun nilainya secara statistik tidak bermakna dengan nilai OR pada hari ke-3 demam untuk neutropeni 1,91 (IK95\% 0,71-5,62; $\mathrm{p}=0,189$ ), nilai OR untuk neutropeni 1,98 (IK95\% 0,67-5,87; $\mathrm{p}=0,22)$ dan monositopeni 1,67 (IK95\% 0,42-6,59; p=0,46) pada hari ke-4 demam. Penelitian yang dilakukan pada pasien anak oleh Suwandono dkk, ${ }^{14}$ Karande dkk, ${ }^{7}$ dan Phuong $\mathrm{dkk}^{11}$ mendapatkan jumlah leukosit dan neutrofil yang lebih rendah pada pasien infeksi dengue dibandingkan dengan bukan dengue, Kalayanarooj $\mathrm{dkk}^{6}$ mencatat bahwa jumlah monosit pada pasien dengue lebih rendah dibandingkan non dengue, dan mencatat perbedaan pada rata-rata hari ke-3 demam.

Limfosit memainkan peran yang penting dalam mekanisme pertahanan terhadap virus dengue. Pada pasien dengue, kami mendapatkan jumlah limfosit tidak berbeda dibandingkan bukan dengue pada hari ke-3 demam, dengan nilai aOR 1,82 (IK95\% 0,505,63; $\mathrm{p}=0,297)$, sedangkan pada hari ke-4 demam menjadi bermakna OR 4,66 (IK95\% 1,73-12,59; $\mathrm{p}=0,002)$. Limfosit belum dapat membedakan infeksi dengue dan bukan dengue pada hari ke-4. Pada hari tersebut dikhawatirkan pasien telah mengalami syok. Penelitian pada pasien dewasa yang dilakukan oleh Chadwick dkk, ${ }^{3}$ Binh dkk, ${ }^{2}$ dan Low $\mathrm{dkk}^{8}$ mendapatkan hasil yang berbeda, yaitu jumlah limfosit pasien dengue lebih rendah dibandingkan bukan dengue. Perbedaan ini mungkin karena pada penelitian ini memakai limfosit relatif, sedangkan pada penelitian sebelumnya memakai limfosit absolut.

Proporsi jenis kelamin kelompok kasus dan kontrol tidak berbeda, sebaliknya lama demam sebelum masuk rumah sakit berbeda. Pada kelompok kasus, pasien datang rata-rata hari ke-3 demam, sedangkan untuk kelompok kontrol, datang pada hari ke 4 demam. Penelitian Sutaryo ${ }^{13}$ mencatat lama demam sebelum masuk rumah sakit pada pasien dengue dan bukan dengue terjadi pada hari ke- 4 atau ke-5 karena pada hari tersebut orang tua sudah memeriksakan anak ke Puskesmas, rumah sakit, atau dokter. Rata-rata lama rawat di rumah sakit untuk kelompok kasus 3,44 40,59 hari, sedangkan untuk kelompok kontrol 4,95 $\pm 2,24$ hari. Hal tersebut sesuai dengan perjalanan penyakit dengue yang akan pulih dan diperbolehkan pulang setelah hari ke-7. Sementara untuk kelompok kasus, persentase demam tifoid tertinggi memerlukan waktu yang lebih lama untuk perawatan.

\section{Kesimpulan}

Leukopeni dan limfositosis pada anak dengan gizi baik merupakan prediktor untuk mendiagnosis infeksi dengue pada hari awal demam.

\section{Daftar pustaka}

1. Ashley EA. Dengue fever. Paper presented at the meeting of trends in Anaesthesia and Critical Care. London: 2010; 39-41.

2. Binh PH, Matheus S, Huong VT. Early clinical and biological features of severe clinical manifestations of dengue in Vietnamese. J Virol 2009; 5:1680-91.

3. Chadwick D, Arch B, Smith A. Distinguishing dengue fever from other infection on the basis of simple clinical and laboratory feature: application of logistic regression analysis. J. Virol 2005;35:147-53.

4. Guglani L, Kabra SK. T cell immunopathogenesis of dengue virus infection. Dengue Bulletin 2005;29:5869.

5. Hadinegoro SR, Satari HI. Demam berdarah dengue. Naskah Lengkap Pelatihan Bagi Pelatih Dokter Spesialis Anak dan Dokter Spesialis Penyakit dalam Tatalaksana Kasus DBD. Jakarta: Fakultas Kedokteran Universitas Indonesia 2001;44-54.

6. Kalayanarooj S, Vaughn DW, Nimmannitya S. Early clinical and laboratory indicators of acute dengue illness. J Infect 1997;176:313-21.

7. Karande S, Gandhi D, Kulkarni M. Concurrent outbreak of leptospirosis and dengue in Mumbai, India. J Trop Pediatr 2005;51:174-81.

8. Low JG, Ooi EE, Tolfvenstam T. Early dengue infection and outcome study (eden) - study design and preliminary findings. Ann Acad Med Singapore 2006;35:783-9.

9. Malavige GN, Fernando S, Fernando DJ. Dengue viral infections. Postgrad Med J 2004;80:588-601.

10. Nany. Limfosit plasma biru nilai diagnostik pada infeksi dengue (tesis). Medan: Fakultas Kedokteran Universitas Sumatra Utara, 2007.

11. Phuong CX, Nhan NT, Kneen R. Clinical diagnosis and assessment of severity of confirmed dengue infections in Vietnamese children. Am J Trop Med Hyg 2004;70:172179.

12. Potts AJ and Rothman AL. Clinical and laboratory features that distinguish dengue from other febrile illnesses in endemic populations. Trop Med Int Health 2010;13:1328-40.

13. Sutaryo. Limfosit plasma biru: arti diagnostik dan sifat 
Adek Herlina Tanjung dkk: Jumlah leukosit, neutrofil, limfosit, dan monosit sebagai prediktor infeksi dengue

imunologik pada infeksi dengue (disertasi). Yogyakarta: Fakultas Kedokteran Universitas Gadjah Mada, 1991.

14. Suwandono A, Nurhayati. Comparison of diagnostic value of platelet, leucocyte, NS1 antigen, and antidengue IgM antibody. J Indon Med Assoc 2011;61:326-32.

15. WHO. Dengue guidelines for diagnosis, treatment, prevention and control, New ed. Geneva: World Health Organization; 2009.

16. WHO. Comprehensive guidelines for prevention and control of dengue and dengue haemorrhagic fever, revised and expanded ed. India: World Health Organization; 2011. 